\title{
Bidens pilosa L. (Asteraceae) control in sunflower with residual herbicides
}

\author{
Alexandre Magno Brighenti ${ }^{*}$, Yago Vieira Guerra Varotto² \\ 'Embrapa Gado de Leite, Coronel Pacheco, Brazil \\ ${ }^{2}$ Centro de Ensino Superior de Juiz de Fora, Juiz de Fora, Brazil \\ *Corresponding author, e-mail: alexandre.brighenti@embrapa.br
}

\begin{abstract}
One of the most damaging species in sunflower crops in Brazil is the hairy beggartick (Bidens pilosa $\mathrm{L}$ ). The large number of seeds, the various vegetative cycles during the year, the staggered germination and the scarcity of selective and effective herbicides to control this weed in sunflower are some of attributes that hinder the control of hairy beggartick populations. Two experiments were carried out to evaluate the control of hairy beggarticks, as well as sunflower tolerance to herbicides. The treatments were as follows: S-metolachlor (1,200 and 2,400 $\left.\mathrm{g} \mathrm{ai} \mathrm{ha}^{-1}\right)$, flumioxazin (60 and $120 \mathrm{~g} \mathrm{ai} \mathrm{ha}^{-1}$ ), and sulfentrazone (150 and $300 \mathrm{~g} \mathrm{ai} \mathrm{ha}^{-1}$ ) and two controls (weedy and weed-free check). The selectivity of the herbicides was higher at low doses. Flumioxazin and sulfentrazone caused injury to sunflowers at the highest doses and mainly in sandy soils. Although S-metolachlor did not cause visual symptoms of injury, the higher dose reduced sunflower yield. The herbicides sulfentrazone and flumioxazin provided satisfactory control of hairy beggartick plants in both types of soils. S-metolachlor presented medium control of hairy beggarticks in clay soil; however, its efficiency was slightly higher when applied in sandy soil. The most efficient herbicide for controlling hairy beggartick plants was flumioxazin, followed by sulfentrazone.
\end{abstract}

Keywords: flumioxazin, Helianthus annuus, S-metolachlor, sulfentrazone, weeds

\section{Introduction}

The genus Bidens (Asteraceae) consists of approximately 230 to 280 species (Bogosavljevic \& Zlatkovic, 2015). Bidens pilosa L., commonly known as hairy beggartick, is one of the most prominent species in agricultural regions in South America, from where it has spread to various parts of the world (Bartolome et al., 2013). In Brazil, it occurs mainly in the central South Region (Santos \& Cury, 2011).

The species is annual and herbaceous, with an erect stem 40-120 cm high (Lorenzi, 2014). The inflorescences, also called heads, are formed by yellow flowers that originate seeds (achenes) (Baio et al., 2013). Hairy beggarticks can produce
3,000 to 6,000 achenes per plant, with viability of germination even after 5 years due to seed dormancy under adverse conditions (Gilbert et al., 2013). Many seeds germinate readily, allowing the species to have three or four generations per year under favorable conditions (Weber, 2017).

Two or three barbed awns at the end of the achenes are essential for spreading the species by adhering to clothes, animal fur, or birds; the achenes also spread by wind and water (Weber, 2017).

Hairy beggartick populations were confirmed in Brazil as resistant to acetolactate synthase (ALS)-inhibiting herbicides (Guerra et al., 2011 ; Heap, 2017), as well as to both ALS inhibitors 
and photosynthesis-inhibiting herbicides (Takano et al., 2016). Hairy beggartick populations were also identified as resistant to paraquat (Njoroge, 1991; Heap, 2017) and glyphosate in Mexico (Alcántara-de la Cruz, 2016).

Hairy beggarticks are considered to be one of the most problematic weed species in Brazilian sunflower fields (Brighenti, 2012). The difficulty in controlling this species is also attributed to its similarities to sunflowers. Both species belong to the same family (Asteraceae) and have morphological and physiological similarities. Generally, selective herbicides for sunflower do not provide effective control of hairy beggarticks. In addition, the scarcity of effective sunflower herbicides to control broadleaf weeds has limited chemical weed management options in the postemergence period of sunflower (Brighenti, 2013).

However, herbicides with residual effects are an alternative practice in weed control in sunflower fields (Týr \& Vavrík, 2015). The dynamics of these herbicides in soils are influenced by various characteristics, such as soil mineralogy, soil texture, moisture content, organic matter and $\mathrm{pH}$ (Freitas et al., 2014; Faustino et al., 2015). Thus, studies of herbicide selectivity as a function of specific conditions are necessary to avoid toxicity on sunflower plants and to obtain effective control of the main weed species.

The objectives of this study were to evaluate the control of hairy beggartick plants in sunflower crops and to assess sunflower tolerance to residual herbicides.

\section{Materials and methods}

Two experiments were carried out in the municipalities of Valença, Rio de Janeiro State, Brazil $\left(22^{\circ} 21^{\prime} 35.29^{\prime \prime} \mathrm{S}, 43^{\circ} 41^{\prime} 40.92^{\prime \prime} \mathrm{W}\right)$ and Coronel Pacheco, Minas Gerais State, Brazil (2132'55.60"S, $43^{\circ} 15^{\prime} 57.58^{\prime \prime} \mathrm{W}$ ). Soils of the experimental sites are classified as Red-Yellow Argisol and Fluvic Cambisol, respectively. Samples of the soil layer (0-20 cm depth) were collected from Valença and Coronel Pacheco for chemical and textural analyses. The results were as follows: $\mathrm{pH}\left(\mathrm{H}_{2} \mathrm{O}\right)=$ 5.2 and $5.1, \mathrm{P}=53.6$ and $24.5 \mathrm{mg} \mathrm{dm}^{-3}, \mathrm{~K}=185$ and $168 \mathrm{mg} \mathrm{dm}^{-3}, \mathrm{Ca}^{2+}=2.0$ and $3.7 \mathrm{cmol}_{\mathrm{c}} \mathrm{dm}^{-3}$, $\mathrm{Mg}^{2+}=0.9$ and $1.4 \mathrm{cmol}_{\mathrm{C}} \mathrm{dm}^{-3}, \mathrm{CEC}_{(t)}=3.4$ and 5.7 $\mathrm{cmol}_{C} \mathrm{dm}^{-3}, \mathrm{CEC}\left(\mathrm{T}_{\mathrm{PH}=7.0}\right)=7.3$ and $10.3 \mathrm{cmol}_{C} \mathrm{dm}^{-3}$, $V=46$ and $54 \%$, organic matter concn. $=2.8$ and $3.3 \mathrm{dag} \mathrm{kg}^{-1}$, clay $=18$ and $56 \%$, silt $=14$ and $35 \%$, and sand $=68$ and $9 \%$ for Valença and Coronel Pacheco, respectively.

The monthly mean air temperatures (maximum and minimum), rainfall and humidity during the experimental periods are shown in Table 1.

Table 1. Average maximum and minimum monthly air temperatures (T), rainfall and maximum and minimum monthly humidity $(\mathrm{H})$ during the experimental periods (Valença, Rio de Janeiro State, and Coronel Pacheco, Minas Gerais State, Brazil)

\begin{tabular}{|c|c|c|c|c|c|c|c|c|}
\hline \multirow{2}{*}{$\frac{\text { Sites }}{\text { Month/Year }}$} & \multicolumn{4}{|c|}{ Valença } & \multicolumn{4}{|c|}{ Coronel Pacheco } \\
\hline & May/16 & Jun/16 & Jul/16 & Agu/16 & May/16 & Jun/16 & Jul/16 & Agu/16 \\
\hline Maximum T $\left({ }^{\circ} \mathrm{C}\right)$ & 26.3 & 23.3 & 19.0 & 20.4 & 20.6 & 17.9 & 18.7 & 20.2 \\
\hline Minimum $\mathrm{T}\left({ }^{\circ} \mathrm{C}\right)$ & 16.0 & 14.10 & 13.9 & 14.6 & 19.3 & 16.7 & 17.2 & 18.5 \\
\hline Rainfall (mm) & 15.0 & 88.4 & 0.2 & 29.8 & 16.4 & 29.0 & 6.6 & 16.8 \\
\hline Maximum H (\%) & 98.0 & 98.0 & 97.0 & 97.0 & 87.1 & 89.3 & 81.1 & 72.0 \\
\hline Minimum H (\%) & 34.0 & 34.0 & 26.0 & 24.0 & 80.7 & 83.8 & 74.4 & 63.6 \\
\hline
\end{tabular}

The layout of the experiments was a complete randomized block design with four replicates. The treatments were as follows: S-metolachlor (1,200 and 2,400 $\left.\mathrm{g} \mathrm{ha}^{-1}\right)$, flumioxazin (60 and $120 \mathrm{~g} \mathrm{ha}^{-1}$ ), sulfentrazone (150 and 300 $\left.\mathrm{g} \mathrm{ha}^{-1}\right)$. Weedy check and weed-free check controls were also added.

The experiments were installed on May 17, 2016 (Valença), and on May 30, 2016 (Coronel Pacheco). The soils of the experimental areas were plowed and harrowed. Then, hairy beggartick seeds were distributed throughout each experimental area in the amount of $0.5 \mathrm{~kg}$ of seeds (approximately 60 seeds $\mathrm{m}^{-2}$ ).

The sunflower hybrid Paraíso $102 \mathrm{CL}^{\circledR}$ (Clearfield $^{\circledR}$ ) was sown with three seeds spaced $25 \mathrm{~cm}$ apart. Each plot consisted of four rows of 3 $\mathrm{m}$ long and $0.8 \mathrm{~m}$ row spacing. The experimental net area was $4.8 \mathrm{~m}^{2}(1.6 \mathrm{~m} \times 3 \mathrm{~m})$. Sprinkler irrigations were performed weekly with a 15- 
$\mathrm{mm}$ water layer. The fertilization at sowing time was $350 \mathrm{~kg} \mathrm{ha}^{-1}$ NPK (08-28-18). The thinning of sunflower plants was carried out ten days after sunflower emergence, maintaining a stand of approximately 50,000 plants per hectare. Sidedressing was performed 18 days after sunflower emergence with $250 \mathrm{~kg} \mathrm{ha}^{-1}$ NPK formulation (2005-20). Boron (B) was applied in mix with the sidedressing fertilizer at $1.2 \mathrm{~kg} \mathrm{ha}^{-1}$ (boric acid - 17\% B). Grass weeds were controlled using fluazifopp-butyl at a dose of $125 \mathrm{~g} \mathrm{ha}^{-1} 15$ days after sunflower emergence (DAE). Broadleaf weeds, which escaped the action of the herbicide treatments, were manually eliminated at 20 DAE, letting only hairy beggarticks establish.

Herbicide treatments were applied in pre-emergence conditions immediately after sowing on May 18, 2016 (Valença), and June 2, 2016 (Coronel Pacheco). All herbicide treatments were applied using a backpack sprayer (Herbicat - Catanduva, São Paulo, Brazil). The spray boom (2.0 m length) contained four flat nozzles (Magno ADGA 1 10.02), spaced $0.5 \mathrm{~m}$ apart, delivering a volume equivalent to $160 \mathrm{~L} \mathrm{ha}^{-1}$. The phytotoxic effects of herbicide treatments on sunflower and hairy beggartick control were evaluated using a visual scale (0\% to 100\%) at 25 and 35 days after application of the treatments (DAT). A value of zero corresponded to no symptoms of injury to sunflower plants or no hairy beggartick control, and $100 \%$ corresponded to complete sunflower death or complete weed control (SBCPD, 1995). The density of hairy beggarticks was determined by counting hairy beggartick plants within an inventory quadrat $(0.5 \times 0.5 \mathrm{~m})$ at 45 DAT. The count of hairy beggartick plants was obtained in one square for each plot. The values of hairy beggartick density were converted to plants $\mathrm{m}^{-2}$.

Sunflower plant stands were determined by counting the number of plants within the central two rows of each plot and converting to plants per hectare. Averages of sunflower plant height and head diameter were obtained by measuring five plants from two central rows. The oil content was determined by nuclear magnetic resonance (NMR) equipment (Oxford, USA). The sunflower yield was obtained by harvesting two 3 $\mathrm{m}$ lines of sunflower within the central area of the plots and a subsequent transformation to $\mathrm{kg} \mathrm{ha}^{-1}$.
The injury to sunflower and hairy beggartick control percentages were normalized by square root transformation of $(x+1)$ to perform analysis of variance tests (Ribeiro Júnior, 2001). Data were subjected to analyses of variance, and the mean values were compared using the Scott-Knott test ( $p \leq 0.05$ ). Statistical analyses were performed using SAEG software (Ribeiro Júnior, 2001).

\section{Results and Discussion}

Treatments with S-metolachlor and sulfentrazone did not cause visual symptoms of injury to sunflower plants at 35 DAT (Tables 2 and 3). Although S-metolachlor is registered and recommended for use with sunflowers, this herbicide can leach under conditions of sandy soil and can thus cause injury to the crop (Monserrsat Delgado, 1994). S-metolachlor was also evaluated on sunflower (Helio 250 hybrid) at a dose of 1,440 $\mathrm{g} \mathrm{ha}^{-1}$ (Reis et al., 2014). The authors considered S-metolachlor a potential herbicide for use in the preemergence of sunflower.

Sulfentrazone (300 $\mathrm{g} \mathrm{ha}^{-1}$ ) was phytotoxic at 25 DAT when applied in sandy soil (Valença), with a percentage of $15 \%$ (Table 2). The sunflowers recovered, and no visual injury symptoms were observed at 35 DAT. The adsorption of sulfentrazone to the soil is influenced by $\mathrm{pH}$, organic matter and clay content (Freitas et al., 2014; Braga et al., 2016; Teixeira et al., 2017). Soils with lower clay and organic matter levels show high potential for sulfentrazone leaching (Faustino et al., 2015). The organic matter content and clay levels were lower in the experiment conducted in Valença when compared to the experiment in Coronel Pacheco. The lower sulfentrazone adsorption in the Valença condition likely allowed sulfentrazone to remain in the soil solution, which caused sunflower injury at 25 DAT.

Sulfentrazone was also applied under preemergence conditions of sunflower in clay soil (77.5\% clay) (Brighenti et al., 2000). The dose of $300 \mathrm{~g} \mathrm{ha}^{-1}$ was tolerated by sunflower (Morgan M-742 hybrid), with low values of injury at 20 DAT and recovery of plants at 30 DAT.

Flumioxazin was the most phytotoxic treatment to sunflower plants. The percentage of injuries reached $31 \%$ and $1.5 \%$ at 25 DAT for 
the lowest dose for the experiments conducted in Valença and Coronel Pacheco, respectively (Tables 2 and 3). The plants recovered, and those values decreased to $21 \%$ and $0 \%$ at 35 DAT, respectively. This herbicide is highly adsorbed by organic matter and clay minerals and, consequently, it is poorly leached on clay soils (Ferrel et al., 2005; Alister et al., 2008; Deuber, 2009). Thus, sunflower injury was greater in sandy soil (Valença) than in clay soil (Coronel Pacheco) due to less flumioxazin remaining bound to the soil.

Table 2. Percentage of injury on sunflower plants (I) and hairy beggartick control (C) at 25 and 35 days after application of the treatments (DAT) and hairy beggartick density (plants $\mathrm{m}^{-2}$ ) (DH), at 45 DAT. Valença, Rio de Janeiro State, 2016

\begin{tabular}{|c|c|c|c|c|c|c|}
\hline \multirow[t]{2}{*}{ Treatments } & \multirow[t]{2}{*}{ Doses $\left(\mathrm{g} \mathrm{ha}^{-1}\right)$} & \multicolumn{2}{|c|}{ I (\%) } & \multicolumn{2}{|c|}{ C (\%) } & \multirow{2}{*}{$\frac{\mathrm{DH}}{45 \mathrm{DAT}}$} \\
\hline & & 25 DAT & $35 \mathrm{DAT}$ & 25 DAT & 35 DAT & \\
\hline S-metolachlor & 1200 & $0.0 \mathrm{D}^{1}$ & $0.0 \mathrm{C}$ & $81.7 \mathrm{D}$ & $83.7 \mathrm{D}$ & $46.8 \mathrm{~B}$ \\
\hline S-metolachlor & 2400 & $0.0 \mathrm{~B}$ & $0.0 \mathrm{C}$ & $91.5 \mathrm{C}$ & $95.0 \mathrm{C}$ & $22.0 \mathrm{C}$ \\
\hline Flumioxazin & 60 & $31.0 \mathrm{~B}$ & $21.0 \mathrm{~B}$ & $97.0 \mathrm{~B}$ & $98.2 \mathrm{~B}$ & $18.8 \mathrm{C}$ \\
\hline Flumioxazin & 120 & $97.7 \mathrm{~A}$ & $99.7 \mathrm{~A}$ & $100.0 \mathrm{~A}$ & $100.0 \mathrm{~A}$ & $10.0 \mathrm{C}$ \\
\hline Sulfentrazone & 150 & $0.0 \mathrm{D}$ & $0.0 \mathrm{C}$ & $99.2 \mathrm{~A}$ & $100.0 \mathrm{~A}$ & $22.8 \mathrm{C}$ \\
\hline Sulfentrazone & 300 & $15.0 \mathrm{C}$ & $0.0 \mathrm{C}$ & $100.0 \mathrm{~A}$ & $100.0 \mathrm{~A}$ & $8.0 \mathrm{C}$ \\
\hline Weedy Check & - & $0.0 \mathrm{D}$ & $0.0 \mathrm{C}$ & $0.0 \mathrm{E}$ & $0.0 \mathrm{E}$ & $120.0 \mathrm{~A}$ \\
\hline Weed-free Check & - & $0.0 \mathrm{D}$ & $0.0 \mathrm{C}$ & $100.0 \mathrm{~A}$ & $100.0 \mathrm{~A}$ & $0.0 \mathrm{C}$ \\
\hline Coeficient of Variation (\%) & & 1.7 & 1.2 & 0.4 & 0.4 & 50.7 \\
\hline
\end{tabular}

Table 3. Percentage of injury on sunflower plants (I) and hairy beggartick control (C) at 25 and 35 days after application of the treatments (DAT) and hairy beggartick density (plants $\mathrm{m}^{-2}$ ) (DH), at 45 DAT. Coronel Pacheco, Minas Gerais State, 2016

\begin{tabular}{|c|c|c|c|c|c|c|}
\hline \multirow[t]{2}{*}{ Treatments } & \multirow[t]{2}{*}{ Doses $\left(\mathrm{g} \mathrm{ha}^{-1}\right)$} & \multicolumn{2}{|c|}{ I (\%) } & \multicolumn{2}{|c|}{$\mathrm{C}(\%)$} & \multirow{2}{*}{$\begin{array}{r}\mathrm{DH} \\
45 \mathrm{DAT}\end{array}$} \\
\hline & & $25 \mathrm{DAT}$ & $35 \mathrm{DAT}$ & 25 DAT & 35 DAT & \\
\hline S-metolachlor & 1200 & $0.0 \mathrm{C}^{1}$ & $0.0 \mathrm{~B}$ & $42.7 \mathrm{D}$ & $52.0 \mathrm{E}$ & $48.8 \mathrm{~B}$ \\
\hline S-metolachlor & 2400 & $0.0 \mathrm{C}$ & $0.0 \mathrm{~B}$ & $53.0 \mathrm{C}$ & $63.0 \mathrm{D}$ & $8.0 \mathrm{C}$ \\
\hline Flumioxazin & 60 & $1.5 \mathrm{~B}$ & $0.0 \mathrm{~B}$ & $95.0 \mathrm{~B}$ & $97.0 \mathrm{~B}$ & $12.0 \mathrm{C}$ \\
\hline Flumioxazin & 120 & $93.2 \mathrm{~A}$ & $98.0 \mathrm{~A}$ & $99.7 \mathrm{~A}$ & $100.0 \mathrm{~A}$ & $4.0 \mathrm{C}$ \\
\hline Sulfentrazone & 150 & $0.0 \mathrm{C}$ & $0.0 \mathrm{~B}$ & $94.2 \mathrm{~B}$ & $95.5 \mathrm{C}$ & $2.8 \mathrm{C}$ \\
\hline Sulfentrazone & 300 & $0.0 \mathrm{C}$ & $0.0 \mathrm{~B}$ & $95.0 \mathrm{~B}$ & $97.0 \mathrm{~B}$ & $6.8 \mathrm{C}$ \\
\hline Weedy Check & - & $0.0 \mathrm{C}$ & $0.0 \mathrm{~B}$ & $0.0 \mathrm{E}$ & $0.0 \mathrm{~F}$ & $178.8 \mathrm{~A}$ \\
\hline Weed-free Check & - & $0.0 \mathrm{C}$ & $0.0 \mathrm{~B}$ & $100.0 \mathrm{~A}$ & $100.0 \mathrm{~A}$ & $0.0 \mathrm{C}$ \\
\hline Coeficient of Variation (\%) & & 3.5 & 0.6 & 0.7 & 0.5 & 66.6 \\
\hline
\end{tabular}

Flumioxazin at doses of 30 and $60 \mathrm{~g}$ ai ha-1 was applied to sunflower plants at the 2- to 4-leaf stage (Jursík et al., 2011). The authors considered the percentages of injury to be acceptable, ranging from $17 \%$ to $24 \%$.

The higher dose of flumioxazin $(120 \mathrm{~g}$ ai $\mathrm{ha}^{-1}$ ) caused death of sunflower plants at 35 DAT for the experiments conducted in Valença (99.7\%) and Coronel Pacheco (98.0\%) (Tables 2 and 3). The tissues of the emerging seedlings are damaged by contact with the product when this herbicide is used in pre-emergent conditions (Oliveira Júnior, 2011). Postemergent application also provides similar characteristic symptoms based on tissue necrosis. Although flumioxazin remains adsorbed to organic matter and clays, it may be readily available in soil solution as a function of water availability (Ferrel et al., 2005). Therefore, heavy rains after application can promote percolation, affecting seed germination and plant establishment.

The doses of flumioxazin and sulfentrazone provided the highest percentages of hairy beggartick control for both experiments, ranging from $95 \%$ to $100 \%$ at 35 DAT (Tables 2 and 3). In addition, these two herbicides reduced the density of hairy beggartick plants. Ratier et al. (2015) also evaluated hairy beggartick control as a function of flumioxazin applied at presowing desiccation. Flumioxazin at doses of 50 and $75 \mathrm{~g} \mathrm{ha}^{-1}$ provided residual control of hairy beggarticks. This same herbicide was also applied to sugarcane straw at a dose of $150 \mathrm{~g}$ ha-1 $^{-1}$ (Carbonari et al., 2010). The percentages of 
hairy beggartick control were satisfactory and ranged from $95 \%$ to $100 \%$.

S-metolachlor at a lower dose provided medium control of hairy beggartick plants, especially in clay soil conditions (42.7 and $52.0 \%$ ) at 25 and 35 DAT, respectively (Table 3 ). However, the control was higher in sandy soil (Table 2) due to the greater amount of herbicide in the soil solution.

S-metolachlor is not registered for hairy beggartick control in Brazil (Rodrigues \& Almeida, 2011). Although it was not recommended for hairy beggartick control, S-metolachlor at doses of $1,440 \mathrm{~g} \mathrm{ha}^{-1}$ to $7,200 \mathrm{~g} \mathrm{ha}^{-1}$ provided reductions in hairy beggartick plant height (Silva et al., 2013). S-metolachlor $\left(1,680 \mathrm{~g} \mathrm{ha}^{-1}\right)$ applied in the pre- emergent stage of maize also presented medium control of hairy beggarticks, with a percentage of $71.5 \%$ at 28 days after emergence (Dan et al., 2010).

The lowest dose of S-metolachlor $(1,200$

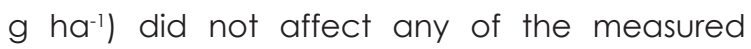
variables and, consequently, did not affect sunflower productivity (Tables 4 and 5). Reis et al. (2014) evaluated S-metolachlor (1,440 $\left.\mathrm{g} \mathrm{ha}^{-1}\right)$ on sunflower. No injury symptoms were detected, and the authors considered s-metolachlor as a potential alternative for weed control in sunflower pre-emergent conditions.

The highest dose of S-metolachlor $(2,400$ $\mathrm{g} \mathrm{ha}^{-1}$ ) caused reductions in sunflower crop yield (Tables 4 and 5).

Table 4. Sunflower plant stand $(\mathrm{S})\left(\right.$ plants ha-1 $\left.\times 10^{4}\right)$, plant height $(\mathrm{H})(\mathrm{m})$, head diameter $(\mathrm{HD})(\mathrm{cm})$, oil content (O) (\%) and sunflower yield (Y) $\left(\mathrm{kg} \mathrm{ha}^{-1}\right)$. Valença, Rio de Janeiro, 2016

\begin{tabular}{|c|c|c|c|c|c|c|}
\hline Treatments & Doses $\left(\mathrm{g} \mathrm{ha}^{-1}\right)$ & $S$ & $\mathrm{H}$ & $\mathrm{HD}$ & $\mathrm{O}$ & Y \\
\hline S-metolachlor & 1200 & $5.5 A^{1}$ & $1.73 \mathrm{~A}$ & $20.6 \mathrm{~A}$ & $43.6 \mathrm{~A}$ & $2,539.5 \mathrm{~A}$ \\
\hline S-metolachlor & 2400 & $4.2 \mathrm{~A}$ & $1.71 \mathrm{~A}$ & $20.5 \mathrm{~A}$ & $42.3 \mathrm{~A}$ & $1,857.2 \mathrm{~B}$ \\
\hline Flumioxazin & 60 & $5.0 \mathrm{~A}$ & $1.74 \mathrm{~A}$ & $20.6 \mathrm{~A}$ & $43.1 \mathrm{~A}$ & $2,208.3 \mathrm{~A}$ \\
\hline Flumioxazin & 120 & $1.0 \mathrm{~B}$ & $1.22 \mathrm{C}$ & $14.1 \mathrm{~B}$ & $42.2 \mathrm{~A}$ & $1,403.1 \mathrm{~B}$ \\
\hline Sulfentrazone & 150 & $5.2 \mathrm{~A}$ & $1.74 \mathrm{~A}$ & $21.0 \mathrm{~A}$ & $42.6 \mathrm{~A}$ & $2,186.4 \mathrm{~A}$ \\
\hline Sulfentrazone & 300 & $5.0 \mathrm{~A}$ & $1.73 \mathrm{~A}$ & $20.7 \mathrm{~A}$ & $42.6 \mathrm{~A}$ & $1,937.5 \mathrm{~B}$ \\
\hline Weedy Check & - & $5.2 \mathrm{~A}$ & $1.48 \mathrm{~B}$ & $15.4 \mathrm{~B}$ & $41.0 \mathrm{~A}$ & $1,998.9 \mathrm{~B}$ \\
\hline Weed-free Check & - & $5.5 \mathrm{~A}$ & $1.75 \mathrm{~A}$ & $21.2 \mathrm{~A}$ & $43.8 \mathrm{~A}$ & $2,552.0 \mathrm{~A}$ \\
\hline Coeficient of Variation (\%) & & 12.7 & 1.6 & 4.9 & 4.1 & 16.7 \\
\hline
\end{tabular}

Table 5. Sunflower plant stand (S) (plants ha-1 $\left.\times 10^{4}\right)$, plant height $(H)(\mathrm{m})$, head diameter (HD) $(\mathrm{cm})$, oil content (O) (\%) and sunflower yield (Y) $\left(\mathrm{kg} \mathrm{ha}^{-1}\right)$. Coronel Pacheco, Minas Gerais, 2016

\begin{tabular}{|c|c|c|c|c|c|c|}
\hline Treatments & Doses $\left(\mathrm{g} \mathrm{ha}^{-1}\right)$ & $S$ & $\mathrm{H}$ & $\mathrm{HD}$ & $\mathrm{O}$ & $Y$ \\
\hline S-metolachlor & 1200 & $5.7 \mathrm{~A}^{1}$ & $1.8 \mathrm{~A}$ & $19.7 \mathrm{~A}$ & $40.8 \mathrm{~A}$ & $3,352.0 \mathrm{~A}$ \\
\hline S-metolachlor & 2400 & $5.5 \mathrm{~A}$ & $1.9 \mathrm{~A}$ & $19.7 \mathrm{~A}$ & $42.5 \mathrm{~A}$ & $2,629.6 \mathrm{~B}$ \\
\hline Flumioxazin & 60 & $5.0 \mathrm{~A}$ & $1.9 \mathrm{~A}$ & $20.5 \mathrm{~A}$ & $43.1 \mathrm{~A}$ & $3,657.2 \mathrm{~A}$ \\
\hline Flumioxazin & 120 & $2.0 \mathrm{~B}$ & $1.5 \mathrm{~B}$ & $14.5 \mathrm{C}$ & $42.2 \mathrm{~A}$ & $2,984.3 \mathrm{~B}$ \\
\hline Sulfentrazone & 150 & $5.2 \mathrm{~A}$ & $1.8 \mathrm{~A}$ & $19.6 \mathrm{~A}$ & $40.5 \mathrm{~A}$ & $3,286.4 \mathrm{~A}$ \\
\hline Sulfentrazone & 300 & $5.7 \mathrm{~A}$ & $1.9 \mathrm{~A}$ & $20.1 \mathrm{~A}$ & $40.3 \mathrm{~A}$ & $3,005.7 \mathrm{~B}$ \\
\hline Weedy Check & - & $4.7 \mathrm{~A}$ & $1.6 \mathrm{~B}$ & $16.3 \mathrm{~B}$ & $41.1 \mathrm{~A}$ & $2,866.6 \mathrm{~B}$ \\
\hline Weed-free Check & - & $5.0 \mathrm{~A}$ & $1.8 \mathrm{~A}$ & $20.6 \mathrm{~A}$ & $40.6 \mathrm{~A}$ & $3,215.1 \mathrm{~A}$ \\
\hline Coeficient of Variation (\%) & & 13.2 & 9.0 & 5.1 & 4.0 & 7.8 \\
\hline
\end{tabular}

The adsorption of S-metolachlor in soils is positively correlated with organic matter and clay content (Gannon et al., 2013; Zemolin et al., 2014). Thus, when S-metolachlor is applied in preemergence conditions, this herbicide is positioned on the soil surface, which is the site of higher concentrations of organic matter (Bedmar et al., 1996; Alletto et al., 2013). High doses of S-metolachlor applied to sandy soils and soils with low organic matter can cause injury to sunflower
(Brighenti et al., 2013). In addition, the leaching potential of S-metolachlor is strictly correlated with rainfall (Inove et al., 2010). Higher doses associated with irrigation water and rainfall can favor the leaching of S-metolachlor to deeper soil layers, affecting the plants and, consequently, reducing crop productivity.

Flumioxazin $\left(60 \mathrm{~g} \mathrm{ha}^{-1}\right)$ did not affect the sunflower crop in any of the evaluated variables (Tables 4 and 5). The selectivity of this herbicide 
to sunflower crops is also dose-dependent. Thus, twice the applied dose caused considerable reductions in all evaluated variables, except the oil content. The sunflower stand was the most drastically affected variable at the highest dose of flumioxazin, which was significantly reflected in yield losses.

Sulfentrazone at the lowest dose did not affect the production components or even the productivity of the sunflowers (Tables 4 and 5). Although no visual symptoms of injury were observed on sunflower plants at 35 DAT, due to the application of the highest dose of sulfentrazone (Tables 2 and 3), there was a reduction in sunflower yields (Tables 4 and 5). Sulfentrazone leaching is dependent on rainfall accumulation and soil texture (Silva Júnior et al., 2016). In times of greater rainfall, sulfentrazone can be found at deeper soil depths, causing damage to crop development. The amount of precipitation during the experiment period was higher in Valença (133.4 mm) than in Coronel Pacheco $(68.8 \mathrm{~mm})$. Additionally, the sand content of the Valença soil is greater than that of the soil from Coronel Pacheco. These conditions may have favored the percolation of sulfentrazone, and consequently, sunflower productivity was lower in Valença than in Coronel Pacheco.

The adsorption of sulfentrazone to the soil is also influenced by $\mathrm{pH}$ and organic matter content (Silva Júnior et al., 2016). The value of organic matter was lower in Valença $(2.8$ dag $\mathrm{kg}^{-1}$ ) than in Coronel Pacheco (3.3 dag $\left.\mathrm{kg}^{-1}\right)$. Consequently, the lower adsorption of the herbicide in soils with lower organic matter content allows a large amount of product to remain in the soil solution, which probably caused greater sunflower yield losses in Valença.

This research provides alternatives for hairy beggartick control in sunflower fields. Different herbicide options that are feasible for use in sunflower can facilitate increases in cultivated areas and grain supplies.

\section{Conclusions}

1. The selectivity of the herbicides was higher at low doses.

2. Flumioxazin and sulfentrazone caused injury to sunflower at the highest doses and mainly in sandy soils.

3. Although S-metolachlor did not cause visual symptoms of injury, the higher dose reduced sunflower yield.

4. The herbicides sulfentrazone and flumioxazin provided satisfactory control of hairy beggartick plants in both types of soils.

5. However, S-metolachlor presented medium control of hairy beggarticks in clay soil; its efficiency was slightly higher when applied in sandy soil.

6. The most efficient herbicide for controlling hairy beggartick plants was flumioxazin, followed by sulfentrazone.

\section{Acknowledgments}

The support from Fundação de Amparo a Pesquisa do Estado de Minas Gerais (FAPEMIG), Conselho Nacional de Desenvolvimento Científico e Tecnológico (CNPq) and also the product engineering consultant Matheus Bohrer Scherer - IHARA is highly appreciated.

\section{References}

Alcántara-de la Cruz, R., Fernández-Moreno, P.T., Ozuna, C.V., Rojano-Delgado, A.M., CruzHipolito, H.E., Domínguez-Valenzuela, J.A., Barro, F., De Prado, R. 2016. Target and non-target site mechanisms developed by glyphosate resistant hairy beggarticks (Bidens pilosa L.) populations from Mexico. Frontiers in Plant Science 7: 1-12.

Alister, C., Rojas, S., Gómez, P., Kogan, M. 2008. Dissipation and movement of flumioxazin in soil at four field sites in Chile. Pest Management Science 64: 579-583.

Alletto, L., Benoit, P., Bolognési, B., Couffignal, M., Bergheaud, V., Dumenéry, V., Langueval, C., Barriuso, E. 2013. Sorption and mineralisation of S-metolachlor in soils from fields cultivated with different conservation tillage systems. Soil Tillage Research 128: 97-103.

Baio, F.H.R., Pires, L.F., Tomquelski, G. 2013. Mapeamento de picão-preto resistente aos herbicidas inibidores de ALS na região sul matogrossense. Bioscience Journal 29: 59-64.

Bartolome, A.P., Villaseñor, I.M., Yang, W.C. 2013. Bidens pilosa L. (Asteraceae): botanical properties, traditional uses, phytochemistry, and pharmacology. Evidence-Based Complementary and Alternative Medicine, 2013: 1-51.

Bedmar, F., Daniel, P.E., Costa, J.L., Giménez, D. 2011 . Sorption of acetochlor, S-metolachlor, and 
atrazine in surface and subsurface soil horizons of Argentina. Environmental Toxicology Chemistry 30: 1990-1996.

Bogosavljevic, S.S., Zlatkovic, B.K. 2015. Two aliens species of Bidens (Compositae), new to the flora of Serbia. Phytologia Balcanica 21: 129-138.

Braga, D.F., Freitas, F.C.L., Rocha, P.R.R., Araújo, A.G.D., Melo, V.C. 2016. Leaching of sulfentrazone in soils from the sugarcane region in the northeast region of Brazil. Planta Daninha 34: 161-169.

Brighenti, A.M., Fornarolli, D.A., Oliveira Júnior, R.S. Gazziero, D.L.P., Pinto, R.A. 2000. Seletividade de herbicidas aplicados em condições de pré-emergência na cultura do girassol. Revista Brasileira de Herbicidas 1: 243-247.

Brighenti, A.M. 2012. Resistência do girassol a herbicidas inibidores da enzima aceto-alctato sintase. Pesquisa Agropecuária Tropical 42: 225230.

Brighenti, A.M. 2013. Manejo de plantas daninhas. In: Oliveira, A.C.B., Rosa, A.P.S.A. Guia prático do cultivo do girassol. Embrapa, Brasília, DF, Brasil. p. 37-42.

Carbonari, C.A., Gomes, G.L.G.C., Velini, E.D. 2010. Efeitos de períodos sem a ocorrência de chuva na eficácia do flumioxazin aplicado no solo e na palha de cana-de-açúcar. Revista Brasileira de Herbicidas 9: 81-88.

Dan, H.A., Barroso, A.L.L., Dan, L.G.M., Finotti, T.R., Feldkircher, C., Santos, V.S. 2010. Controle de plantas daninhas na cultura do milho por meio de herbicidas aplicados em pré-emergência. Pesquisa Agropecuária Tropical 40: 388-393.

Deuber, R., Pastre, W., Giusto A.B. 2009. Lixiviação de flazasulfuron e flumioxazin em dois diferentes solos. Revista Brasileira de Herbicidas 8: 27-36.

Faustino, L.A., Freitas, M.A.M., Passos, A.B.R.J., Saraiva, D.T., Faria, A.T., Silva, A.A., Ferrreira, L.R. 2015. Mobilidade do sulfentrazone em solos com diferentes características físicas e químicas. Planta Daninha 33: 795-802.

Ferrell, J.A., Vencill, W.K., Xia, K., Grey, T.L. 2005. Sorption and desorption of flumioxazin to soil, clay minerals and ion-exchange resin. Pest Management Science 61: 40-46.

Freitas, M.A.M., Passos, A.B.R.J., Torres, L.G., Moraes, H.M.F., Faustino, L.A., Rocha, P.R.R., Silva, A.A. 2014. Sorção do sulfentrazone em diferentes tipos de solo determinada por bioensaios. Planta Daninha 32: 385-392.

Gannon, T.W., Hixson, A.C., Weber, J.B., Shi, W., Yelverton, F.H., Rufty, T.W. 2013. Sorption of simazine and S-metolachlor to soils from a chronosequence of turfgrass systems. Weed Science 61: 508-514.

Gilbert, B., Alves, L.F., Favoreto, R. 2013. Bidens pilosa L. Asteraceae (Compositae; subfamília Heliantheae). Revista Fitos 8: 1-72.

Guerra, N., Oliveira Júnior, R.S., Constantin, J., Oliveira Neto, A.M., Dan, H.A., Alonso, D.G., Santos, G., Jumes, T.M.C. 2011. Efeito da modalidade de aplicação sobre o controle de Bidens pilosa resistente a herbicidas inibidores da enzima ALS. Global Science and Technology 4: 61-69.

Heap, I. 2017. International Survey of herbicide resistant weeds. Disponível em: http:// WwW. weedscience.org/Summary/species. aspx?WeedID=32. (acesso: Junho 2017).

Inove, M.H., Santana, D.C., Oliveira Júnior, R.S., Clemente, R.A., Dallacort, R., Possamai, A.C.S., Santana, C.T.C., Pereira, K.M. 2010. Potencial de lixiviação de herbicidas utilizados na cultura do algodão em colunas de solo. Planta Daninha 28: 825-833.

Jursík, M., Andr, J., Holec, J., Soukup, J. 2011. Efficacy and selectivity of post-emergent application of flumioxazin and oxyfluorfen in sunflower. Plant Soil Environment 57: 532-539.

Lorenzi, H. 2014. Manual de identificação e controle de plantas daninhas: plantio direto e convencional. Instituto Plantarum, Nova Odessa, Brasil. 379 p.

Monserrat Delgado, A. 1994. Daños de herbicidas em los cultivos: sus causas y sintomas. Madri: Ministério de Agricultura, Pesca y Alimentación. $86 \mathrm{p.}$

Njoroge, J. M. 1991. Tolerance of Bidens pilosa L. and Parthenium hysterophorus L. to paraquat (Gramoxone) in Kenya coffee. Kenya Coffee: 999-1001.

Oliveira Júnior, R.S. 2011. Mecanismos de ação de herbicidas. In: Oliveira Júnior, R.S., Constantin, J., Inove, M.H. Biologia e manejo de plantas daninhas. Omnipax, Curitiba, Brasil. p. 141-191.

Ratier, F.J.P., Guerra, N., Oliveira Neto, A.M. 2015. Efeito de misturas de herbicidas na dessecação pré-semeadura e no desenvolvimento inicial do milho safrinha. Revista Campo Digit@l: Ver. Ciências Exatas e da Terra e Ciências Agrárias 10: 63-70.

Reis, R.M., Silva, D.V., Freitas, M.S., Reis, M.R., Ferreira, E.A., Sediyama, T. 2014. Aspectos fisiológicos e crescimento do girassol após aplicação de herbicidas em pré-emergência. Revista Agro@ambiente Online 8: 352-358. 
Ribeiro Júnior, J. I. 2001. Análises estatísticas no SAEG. Editora UFV, Viçosa, Brasil. 301 p.

Rodrigues, B.N., Almeida, F.S. 2011. Guia de herbicidas. Grafmarke, Londrina, Brasil. 697 p.

Santos, J.B., Cury, J.P. 2011. Picão-preto: uma planta daninha especial em solos tropicais. Planta Daninha 29: 1159-1171.

Silva, R.A., Oliveira, L.S., Matsumoto, S.N., Oliveira, M.N.; Costa, A.A. 2013. Crescimento de picão-preto em resposta à aplicação de S-metolachlor. Enciclopédia biosfera, Centro Científico Conhecer 19: 1-7.

Silva Júnior, A.C., Queiroz, J.R.G., Martins, D. 2016. Leaching of sulfentrazone herbicide in soils with different textures. Científica 44: 575-583.

(SBCPD). 1995. Sociedade Brasileira da Ciência das Plantas Daninhas. Procedimentos para instalação e análise de experimentos com herbicidas. SBCPD, Londrina, Brasil. 42 p.

Takano, H.K., Oliveira Júnior, R.S., Constantin, J., Braz, G.B.P., Franchini, L.H.M., Burgos, N.R. 2016. Multiple resistance to atrazine and imazethapyr in hairy beggarticks (Bidens pilosa). Ciência e Agrotecnologia 40: 547-554.

Teixeira, M.F.F., Andrade, L.C.L., Biesdorf, E.M., Biesdorf, E.M., Souza, W.M., Paixão, G.P., Freitas, N.M. 2017. Lixiviação do sulfentrazone em solos do norte de Minas Gerais cultivados com cana-de-açúcar. Revista Brasileira de Herbicidas 16:246-255.

Týr, S., Vavrík, D. 2015. Chemical weed control of sunflower stands. Research Journal of Agricultural Science 47: 243-251.

Weber, E. 2017. Plant Species of the World: A Reference Guide to Environmental Weeds. CABI.

Zemolin, C.R., Avila L.A., Cassol, G.V., Massey, J.H., Camargo, E.R. 2014. Environmental fate of S-me 